\title{
A Review of Desalination Potential in Greek Islands Using Renewable Energy Sources, a Life Cycle Assessment of Different Units
}

\author{
By Karvounis Panagiotis*
}

\begin{abstract}
The scarcity of water is a long-standing problem in Greek islands. The government, as a temporary solution adopted the transportation of water using tanker ships. This type of water is of low quality non-potable and in some cases inappropriate for any use. Apart from that water transportation increases the carbon footprint of the islands that it is already stained due to the big thermal power plants that feed the grid using fossil fuels (mainly diesel). Apart from the environmental issues the economic consequences are extremely high. The cost of transported water in Dodecanese and Cyclades reached a total of 73,5 million $€$ from 2002 to 2010 . The aim of this paper is to bring forward the proposed solutions for desalination of sea water using renewable energy sources, as Greek islands have a great wind and solar potential that is hard to find in any other place on Europe. A Life Cycle Assessment is been conducted between two different desalination technologies (RES and Diesel operating desalination) to fully understand the impact these units have to the environment.
\end{abstract}

Keywords: Desalination, Renewable energy, Greek islands, carbon footprint, reverse osmosis, LCA

\section{Introduction}

Water scarcity is a timeless problem of Greek islands which lead to huge amounts of low quality and not potable water being transported to them with tanker ships. All this water is being subsidized by the Greek government [1]. Thus, the cost may reach $10 € / \mathrm{m}^{3}$. [14] Furthermore, on summer the water demand doubles and in some cases, triples due to tourism bloom in the last 6 years. All Greek islands are not connected to the terrestrial national grid therefore there are small grids in each group of islands. These grids are supplied with power, produced by fossil fuels (mainly diesel), a method that increases, not only the cost of $\mathrm{KWh}_{\mathrm{e}}$ more than twice, but their carbon footprint as well [5]. Since 2010 renewable energy has penetrated the total energy production of islands and now covers $21,8 \%$ of their needs ${ }^{1}$. [34]

In order to tackle the problem, desalination systems, have been developed in some islands but most of them use power from their grid to produce fresh water or independent units, exist operating with diesel. Facing this situation many research brought forward the need of renewable energy sources for sustainable desalination. A desalination system using wind power can achieve huge capacity factor (approx.. $250 \mathrm{~m}^{3} /$ day) with water cost of $2 € / \mathrm{m}^{3}$. A PV based desalination unit needs more space

\footnotetext{
${ }^{1}$ Data from January to December 2015
} 
to achieve the same capacity factor and the cost of water is approximately $7,7 € / \mathrm{m}^{3}$. [6] As the most expensive way is considered the Organic Rankine Cycle desalination, as it requires significant installation costs. [7]

The aim of this paper is to bring forward the need for autonomous desalination plants using renewable energy sources to cover their needs. In those cases reverse osmosis desalination method is preferred as it is easy to install and operate and the specific energy needed per cubic meter is low [2],[3],[4]. The grid independent desalination plants using RES help in clean water production, independency from the low quality transported water, significantly lower energy consumption, reduce the carbon footprint and maintain sustainability in the islands.

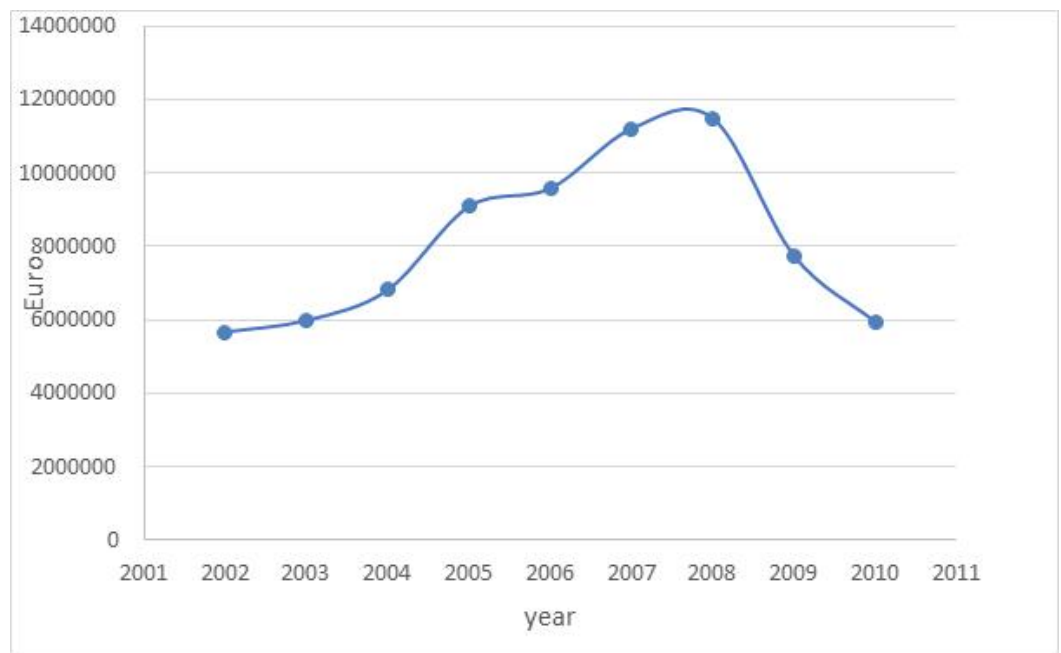

Fig.1: cost of transported water in Dodecanise and Cyclades from 2002 to 2010

\subsection{Current Situation in Greek islands}

The Greek islands separate in tow main categories. The Ionian Sea islands and the Aegean Sea islands. In the Ionian Sea, the rainfall is intensive during winter and there is no significant requirement of fresh water [fig.2]. On the other hand, Aegean Islands face a severe lack of water especially during summer months. The boost on tourism the last years intensifies the problem of water scarcity [8]. The Aegean Islands can be further divided in large and small islands. Larger islands usually have a sufficient water network contrary to the smaller ones that water supply is served by private wells and tanks. [9]

To tackle the situation the Greek government proceeded in the transportation of water with tanker ships. Some data about the amount of transported water in Greek islands in Aegean sea are demonstrated in fig.3. The transportation causes three crucial problems. Firstly, the cost for the government is huge and requires a significant amount of the seasonal budget which reaches approximately 6 to 12 million $€$ /year, an amount really high for a country that faces the economic crisis. [10] Furthermore, the environmental impact of transportation is significantly high as tanker ships have a huge $\mathrm{CO}_{2}$ footprint that adds the already busy footprint that thermal power plants contribute. Last but not least, water transportation doesn't give a permanent solution to the problem that Aegean 
Islands face.

In many cases due to tourism boost the water quantity that is been transported is insufficient because the population on the big islands of Aegean expands dramatically.

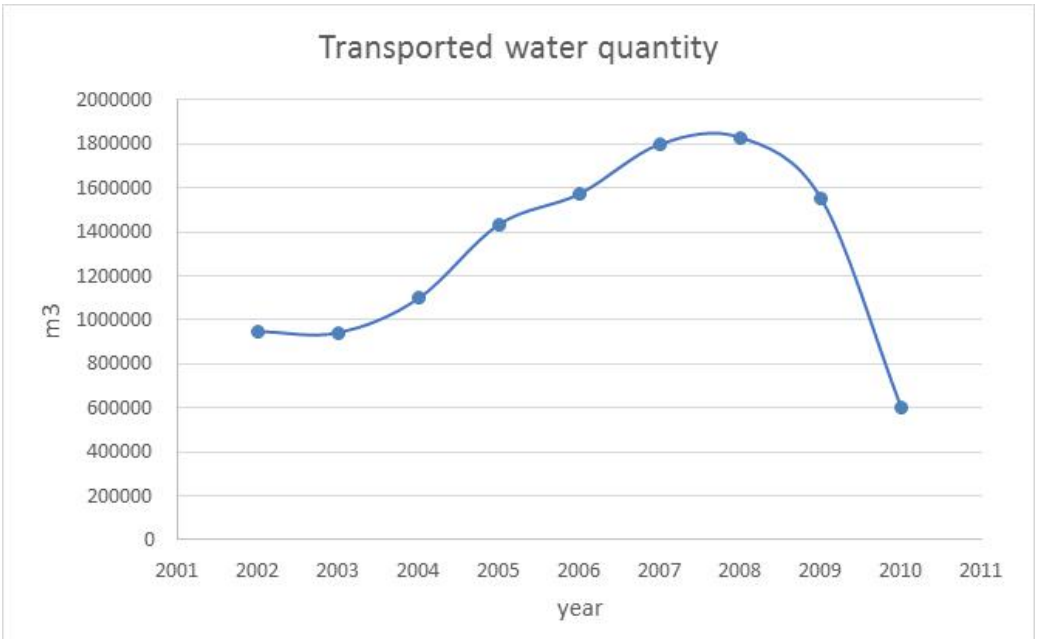

Fig. $3^{2}$ : Transported water quantity from 2002 to 2010. The total water transported was $10.808 .903 \mathrm{~m}^{3}$

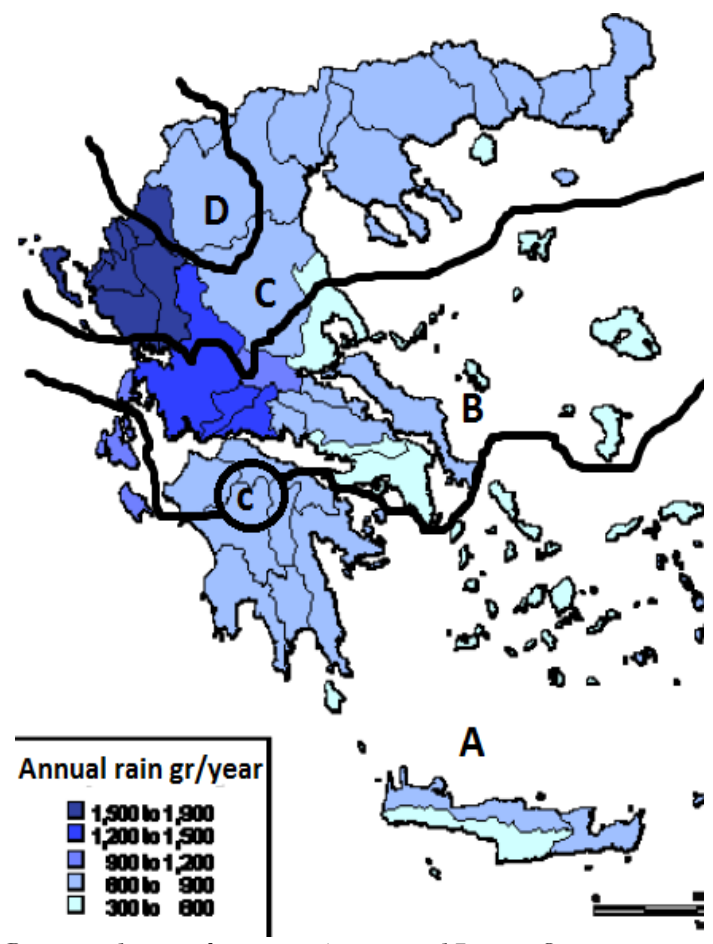

Fig.2: Climatic Zones in Greece and annual rain in Aegean and Ionian Sea

2 The 2010 results defer to the period January-May 


\subsection{Current Desalination Status of the Islands}

The current situation concerning the desalination infrastructures and operation is categorized in thermal processes and membrane processes. Thermal processes require low pressure steam or hot water at $70^{\circ} \mathrm{C}$ while membrane processes require energy to pressurize water from a membrane. The energy that membrane processes (like reverse osmosis which is mainly used) is produced by fossil fuels or renewable energy. Only the last ten years, renewable desalination has dominated in the islands. Traditionally since $80 \mathrm{~s}$ fossil fuel operating units used to be build. Table 1 is an example of installed desalination units in Aegean Islands. The main problem with fossil fuel operating units is that they use power from the local grid of each island. [11] In Greece there are 32 autonomous thermal power plants using diesel to cover their needs. [35]

- 19 small autonomous grids with peak need of 10MW.

- 11 middle sized grids with peak need from 10MW to 100MW.

- 2 big size autonomous grids with peak need above 100MW (Rodes and Crete). Therefore reverse osmosis, a technique that requires a significant amount of energy, burdens the local society economically and environmentally. [12] [13]

Table 1: Desalination Units in Aegean Sea using fossil fuels

\begin{tabular}{cccc}
\hline Location & Capacity $\left[\mathrm{m}^{\mathbf{3}} / \mathbf{d a y}\right]$ & Year of constriction & $\begin{array}{c}\text { Method of Desalination } \\
\text { Syros }\end{array}$ \\
$27.370(14$ units $)$ & Began 1992 & $\begin{array}{c}\text { Reverse Osmosis and Solar } \\
\text { thermal Desalination and MSF }\end{array}$ \\
\hline Ios & 1.000 & 2001 & Reverse Osmosis \\
\hline Mykonos & $9.250(5$ units $)$ & Begam 1989 & Reverse Osmosis \\
\hline Paros & 1.200 & 2002 & Reverse Osmosis \\
\hline Sifnos & 500 & 2001 & Reverse Osmosis \\
\hline Tinos & 500 & 2001 & Reverse Osmosis \\
\hline Santorini & 380 & 1995 & Reverse Osmosis \\
\hline Megisti & 50 & 1990 & Reverse Osmosis \\
\hline Nisiros & 650 & 2002 & Reverse Osmosis \\
\hline
\end{tabular}

Source: Aegean and Island Policy Ministry

Since 2010 Renewable desalination is preferred as an economic and sustainable solution to the problem. Table 2 presents the method and the capacity of desalination units been built since 2013. The most innovative of all the installed unites was the floating desalination unit in Irakleia that operates using a $30 \mathrm{~kW}$ wind turbine and PV panels. The capacity of this unit is $80 \mathrm{~m}^{3} /$ day and costed 1.5 milion euros in 2010 .

Table 2: Renewable Desalination in Aegean Islands

\begin{tabular}{ccc}
\hline Location & Capacity $\left[\mathrm{m}^{3} /\right.$ day $]$ & Technology \\
\hline Kimolos & 576 & Low enthalpy Geothermal Energy \\
\hline Irakleia & 80 & $30 \mathrm{~kW} \mathrm{WT}$ and PV \\
\hline Milos & $3600(3$ units $)$ & $850 \mathrm{~kW} \mathrm{WT}$ \\
\hline Symi & 360 & MVC \\
\hline Strogili & 20 & $10 \mathrm{kWp} \mathrm{PV}$ \\
\hline
\end{tabular}




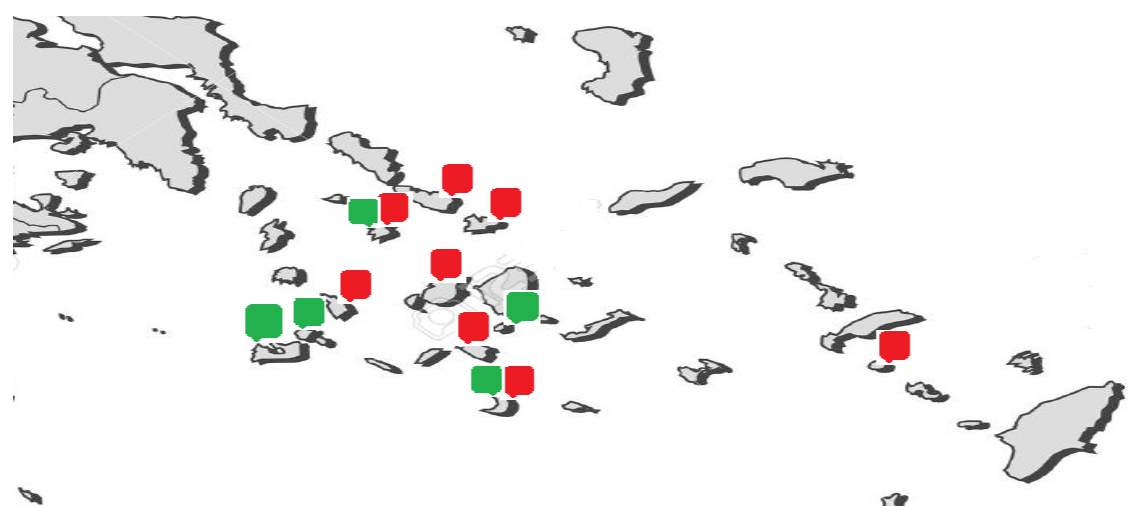

Fig.3: Installed desalination units using Fossil Fuels (red ones) and Renewable Energy (green ones)

\section{Environmental Impact on the Islands}

At this chapter a Life Cycle Assessment comparison between two different technologies is being conducted, in order to determine the environmental impact of each one. The desalination systems compared are one in Milos island, which uses renewable energy and one in Paros operating with power from the grid (means fossil fuels, mainly diesel).

Life Cycle Assessment (LCA) is a methodology for evaluation the environmental impact of a product or a process during their life cycle. Mainly this technique used on building sector [18] but lately is been used to assess any procedure as well as wind turbines and PV panels. [19] [20] LCA is based on the ISO 14040 and consists of four steps: defining the goal, create the inventory, assess the impact and interpret the results. [21]

As the carbon footprint of the Aegean islands is really big due to water transportation and diesel operating thermal power plants we need to determine the impact of the desalination units in order to be able to fully assess the situation. Being able to reduce environmental impact, local authorities save money and boost tourism rating. The goal of this Life Cycle Assessment is to give a clear image of the impact of each technology (renewable energy and diesel operating units) to the environment of the islands. At this study, we consider as main environmental impacts the embodied carbon dioxide (EC) and embodied energy (EE).

Another source of environmental encumbrance is the so-called brine, which is the high salinity water that produced by desalination procedure. Moreover, the chemical discharges to the marine environment affect the water salinity and local ecosystem. [22] For Reverse Osmosis procedure, that interests us, rejected brine is deposited in water ecosystems in significantly high temperature and along with additives like chlorine and halogenated organics and cleaning chemicals that filters use, may cause the disruption of the local environment. [24]

Embodied Carbon $=\sum_{i=1}^{n} Q_{i} * E F_{i}$

Embodied Energy $=\sum_{i=1}^{n} Q_{i} * E E C_{i}$

Where:

$Q_{i}$ is the quantity of the material 
$E F_{i}$ is the emission factor of material $i$

$E E C_{i}$ is the embodied energy coefficient of the material $i$

Table 3. Case studies we apply the LCA method to compare.

\begin{tabular}{ccccc}
\hline Location & Primal Source of Energy & Technology & Capacity [ $\left.\mathbf{m}^{\mathbf{3}} / \mathbf{d a y}\right]$ & \\
\hline Milos & Wind Turbine & Reverse Osmosis & 1200 & CASE 1 \\
\hline Paros & Diesel & Reverse Osmosis & 1200 & CASE 2 \\
\hline
\end{tabular}

\subsection{CASE 1}

\subsubsection{Implementation}

At this study we consider a wind turbine of $850 \mathrm{~kW}$ that is the one that operates in Milos desalination plant. The RO unit is constituted from a CRTE-2-7 pump and XLE-4012 membrane. The estimation of the embodied carbon and embodied energy at Table 5 refer to $1 \mathrm{~m}^{3} /$ day production, therefore, for $1200 \mathrm{~m}^{3} /$ day capacity the final results multiplied.

Table4. Estimation of embodied energy and embodied carbon of a typical wind turbine ${ }^{3}$ [16]

\begin{tabular}{|c|c|c|c|c|c|c|}
\hline & & $\begin{array}{c}\text { Mass } \\
\text { [tn] }\end{array}$ & $\mathrm{EF}\left[\mathrm{CO}_{2} / \mathrm{ton}\right]$ & $\begin{array}{c}\text { EEC } \\
\text { [GJ/ton] }\end{array}$ & $\begin{array}{l}\text { Embodied CO2 } \\
\text { [tons } \mathrm{CO}_{2} / \text { ton] }\end{array}$ & Embodied Energy [GJ] \\
\hline \multirow[t]{8}{*}{ Blades } & Aluminum & 0,11 & 1,13 & 88,07 & 0,13 & 10,01 \\
\hline & Fibre Glass & 4,26 & 4,60 & 56,82 & 19,61 & 242,12 \\
\hline & Epoxy resin & 2,56 & 3,36 & 79,15 & 8,59 & 202,37 \\
\hline & Polyethene & 0,40 & 1,10 & 47,22 & 0,44 & 18,78 \\
\hline & PVC & 0,84 & 1,37 & 43,86 & 1,15 & 36,76 \\
\hline & Paint & 3,07 & 2,02 & 38,64 & 6,21 & 118,54 \\
\hline & Rubber & 0,11 & 1,81 & 57,78 & 0,21 & 6,57 \\
\hline & Iron & 0,85 & 1,09 & 14,20 & 0,92 & 12,11 \\
\hline \multicolumn{7}{|c|}{ Towers } \\
\hline & Steel & 81,93 & 1,56 & 13,86 & 128,02 & 1135,87 \\
\hline & Galvanized steel & 3,81 & 1,60 & 22,16 & 6,10 & 84,36 \\
\hline \multicolumn{7}{|c|}{ Generator } \\
\hline & Copper & 8,75 & 2,18 & 28,41 & 19,04 & 248,58 \\
\hline & Steel & 32,39 & 4,01 & 69,66 & 129,91 & 2256,00 \\
\hline \multicolumn{7}{|c|}{ Nacelle } \\
\hline & Steel & 5,68 & 1,52 & 27,50 & 8,65 & 156,25 \\
\hline & Cast Steel & 2,10 & 1,61 & 14,43 & 3,38 & 30,34 \\
\hline & Iron & 11,93 & 1,08 & 14,77 & 12,88 & 176,27 \\
\hline & Polyester resin & 1,25 & 1,10 & 64,20 & 1,38 & 80,26 \\
\hline & Electronics & 1,42 & 1,55 & 45,74 & 2,20 & 64,97 \\
\hline
\end{tabular}

The total Embodied Energy in an $850 \mathrm{~kW}$ wind turbine is 4880,15 GJ while the total Embodied $\mathrm{CO}_{2}$ is 341,8 tons $\mathrm{CO}_{2} /$ ton. The theoretical disposal scenario of a wind turbine reaches $100 \%$ as all of the above materials are recyclable.

3 The results have been adjusted to an $850 \mathrm{~kW}$ wind turbine 

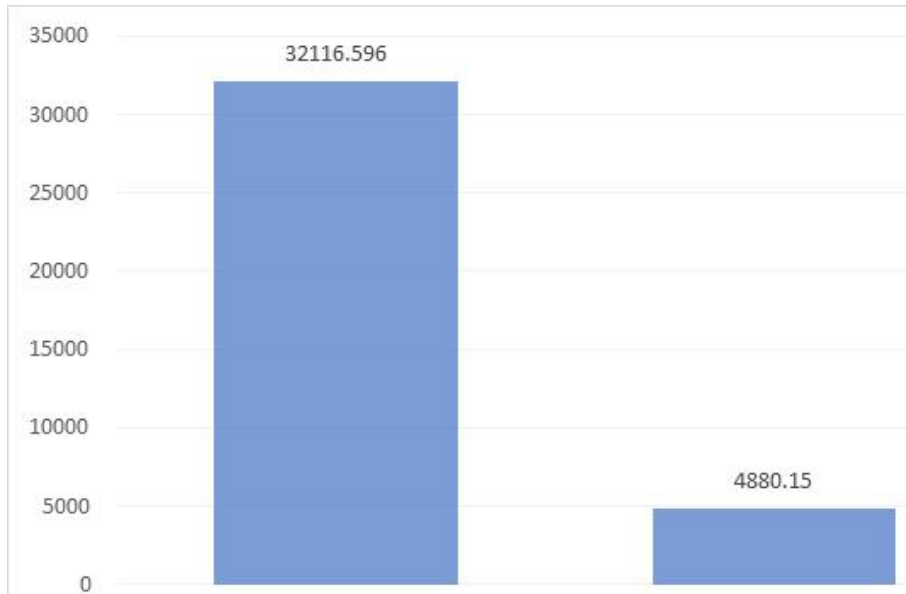

Fig. 4: Embodied Energy (GJ) in $1200 \mathrm{~m}^{3} / \mathrm{d} \mathrm{RO}$ unit and $850 \mathrm{~kW}$ Wind turbine

Table 5. Estimation of embodied carbon and embodied energy on a Desalination unit using reverse osmosis technology.

\begin{tabular}{|c|c|c|c|c|c|c|c|}
\hline & & & $\begin{array}{c}\text { Mass } \\
{[\mathrm{kg}]}\end{array}$ & $\begin{array}{c}\mathrm{EF} \\
{\left[\mathrm{CO}_{2} / \mathrm{kg}\right]}\end{array}$ & $\begin{array}{c}\text { EEC } \\
{[\mathrm{MJ} / \mathbf{k}} \\
\mathrm{g}]\end{array}$ & $\begin{array}{l}\text { Embodied } \\
\quad \mathrm{CO} 2 \\
{\left[\mathrm{kgCO}_{2} / \mathrm{kg}\right]}\end{array}$ & $\begin{array}{c}\text { Embodied Energy } \\
{[\mathrm{MJ}]}\end{array}$ \\
\hline \multicolumn{8}{|l|}{$\begin{array}{l}\text { pressure } \\
\text { vessels }\end{array}$} \\
\hline & RO module & fiber glass & 11,28 & 2,60 & 30,30 & 29,33 & 341,78 \\
\hline & feed spacer & polypropylene & 3,68 & 3,61 & 95,40 & 13,28 & 351,07 \\
\hline \multicolumn{8}{|l|}{ piping } \\
\hline & $\begin{array}{l}\text { High pressure } \\
\text { pipe }\end{array}$ & $\begin{array}{l}10 \% \text { steal } \\
90 \% \text { polypropylene }\end{array}$ & 6,71 & 3,43 & 89,06 & 22,99 & 597,59 \\
\hline \multicolumn{8}{|l|}{ reservoir } \\
\hline & premate tank & $\begin{array}{l}80 \% \text { PVC } \\
20 \% \text { plastic }\end{array}$ & 4,2 & 2,32 & 78,20 & 9,73 & 328,44 \\
\hline \multicolumn{8}{|l|}{ motor } \\
\hline & $7,5 \mathrm{~kW}$ & $\begin{array}{l}90 \% \text { steel } 5 \% \text { iron } \\
5 \% \text { cooper }\end{array}$ & 130 & 6,62 & 32,74 & 861,12 & 4255,55 \\
\hline
\end{tabular}

\begin{tabular}{|l|c|c|c|}
\hline & & & Type \\
\hline Embodied Energy & Pump & $509,4 \mathrm{MJ}$ & CRTE 2-7 \\
\hline Embodied Energy & Membrane & 20380MJ & XLE 4021 \\
\hline
\end{tabular}

The above data are for a typical RO unit operating with a motor of 7,5 $\mathrm{kW}$ and for 1 $\mathrm{m}^{3} /$ day production. [23] The total embodied energy in the $\mathrm{RO}$ unit is 26763,83 $\mathrm{MJ} / \mathrm{m}^{3}$ producted water or $32.116 \mathrm{GJ}$ for the hole unit.

\subsection{CASE 2}

\subsubsection{Implementation}

At this case, we consider the same desalination unit as the embodied energy and embodied $\mathrm{CO}_{2}$ doesn't show a significant alteration between different types of RO units as it has been studied in [23]. Therefore, the main change in the environmental footprint of the units is the type of fuel. In Paros case the motors and the pump of the unit are 
connected to the local grid.

Diesel engines are characterized by concentration of power, low efficiency and a lot of heat waste along with harmful emissions to the environment. Due to isolation from terrestrial grid, Paros island, imports each year diesel to cover its $9.964 \mathrm{MWh}_{\mathrm{e}}$ needs. The desalination unit of the island uses $850 \mathrm{~kW}$ of equivalent diesel to operate.

The total embodied energy of a liter of diesel fuel equals to 45,71 MJ. To follow the $850 \mathrm{kWh}$ consumption 66,98 liters needed so the total embodied energy appropriate for this desalination unit is 3061,74 MJ. [36] The point that needs to be mentioned here is that for the hole year diesel consumes this energy contrary to the wind turbine. So, for the hole year the embodied energy to the diesel engine is $26.790 .225 \mathrm{GJ} / \mathrm{year}$. The embodied $\mathrm{CO}_{2}$ for a year is 2231 tonsCO $\mathrm{CO}_{2}$.

\subsubsection{Results}

At this stage, we assess the results of the LCA method on the two Cases. Noticing fig. 6 we understand that more energy is needed to manufacture a wind turbine rather than a diesel engine production. However, for a year operation (8750h) the diesel engine requires 250 times more energy. For the carbon footprint diesel requires 4 times more $\mathrm{CO}_{2}$ to produce a $\mathrm{kW}$ of energy. WT embodied carbon is found during manufacturing process and after that it operates with zero $\mathrm{CO}_{2}$ emissions. Concluding, the Renewable energy unit doesn't burden the island with further environmental impact while the diesel operating unit constantly adds a great amount of $\mathrm{CO}_{2}$ to the local environment.

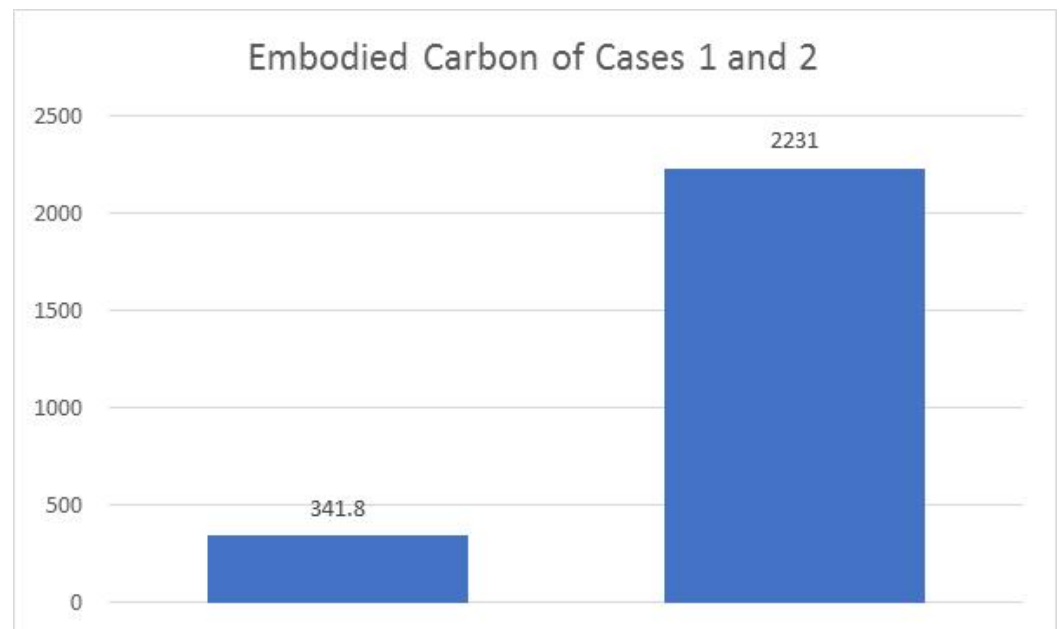

Fig.5: Embodied $\mathrm{CO}_{2}$ in two Cases in tons 


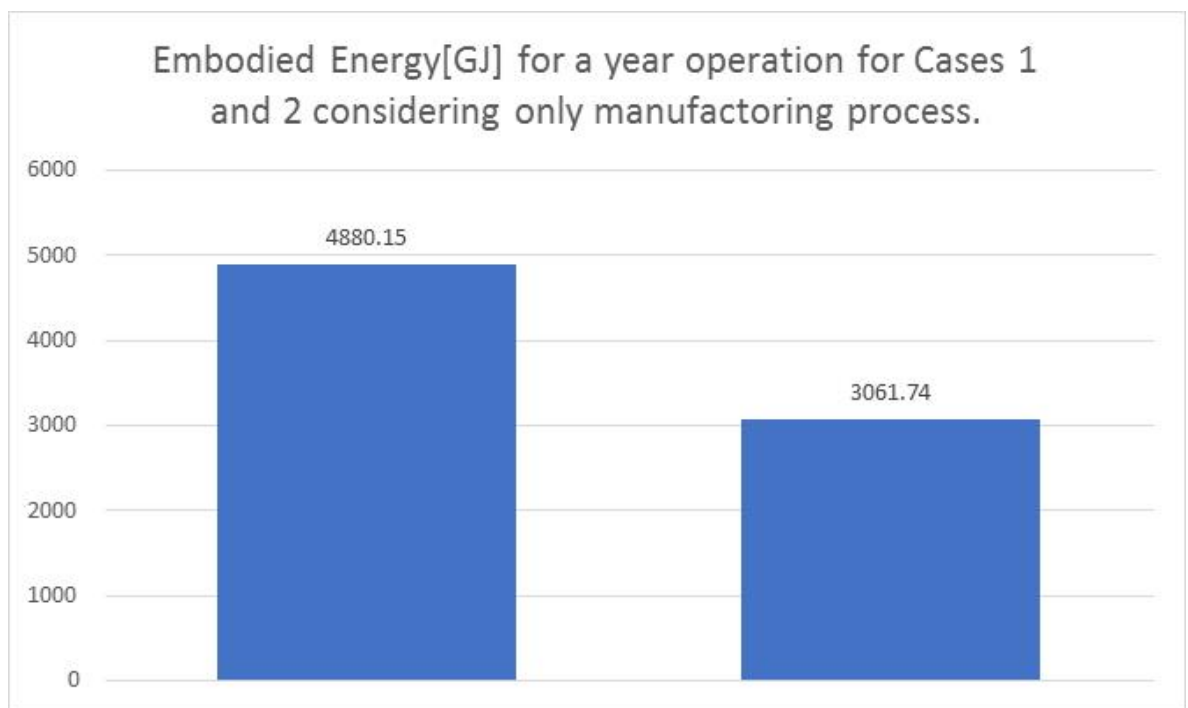

Fig.6: Embodied energy between case 1 and 2 considering only manufacturing process

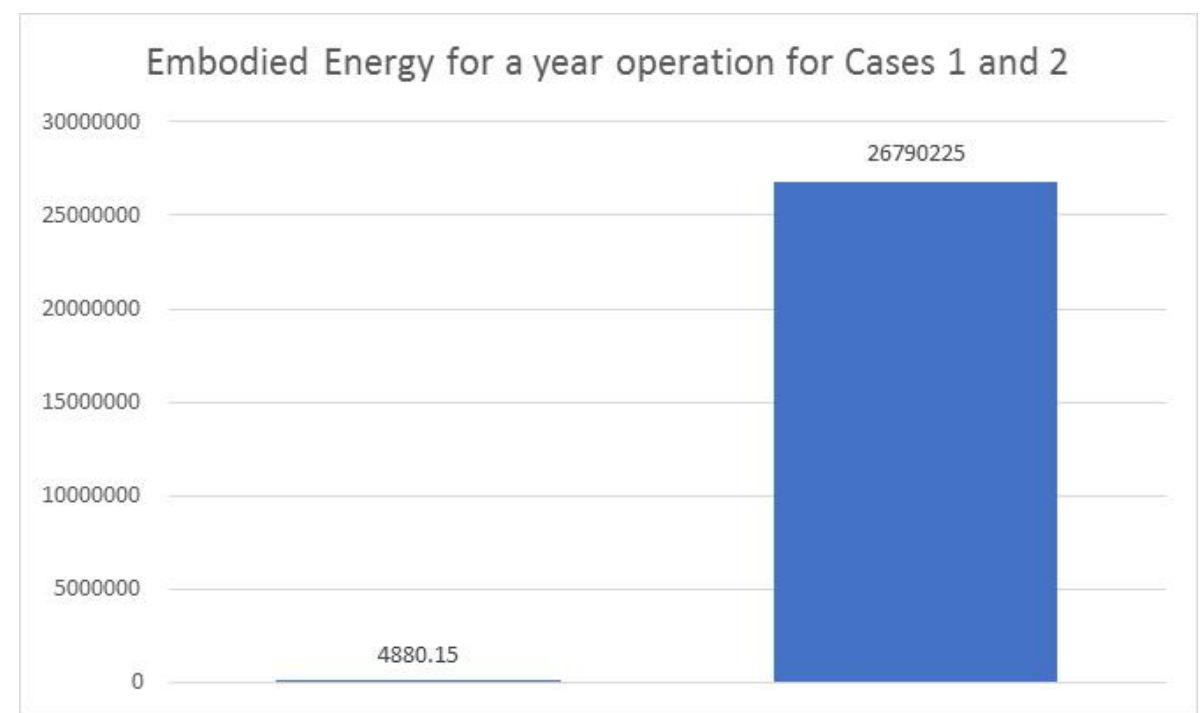

Fig.7: Embodied Energy in GJ for Cases 1 and 2

\section{Renewable Energy Desalination Potential in Dodecanise and Cyclades}

In an attempt to overcome the serious situation of fresh, potable water shortage problem, renewable energy desalination has been proposed as a sustainable solution. In the last 10 years, there was a boost on renewable energy sources installation (especially wind farms) however the fluctuation of seasonal load leads to under-consumption at low consumption periods (October-April) and the electricity can't be absorbed by the local grid. That leaves islands with plenty energy for sustainable desalination units. 
Apart from that solar irradiance is abundant both in Dodecanese and Cyclades and can reach $1950 \mathrm{kWh} / \mathrm{m}^{2}$ and $1800 \mathrm{kWh} / \mathrm{m}^{2}$ respectively as it is seen in fig.9. Combining that with the fact that the terrain is ideal for the use of solar panels, solar driven desalination plants could be easily installed. In fact, Karimi et. al [13], Karagiannis et. al [11], Wei He [3], Helal et. al [20], have presented full studies of PV driven desalination units that operate either with or without storage in order to produce fresh water. Using the software provided by the European Commission (http://re.jrc.ec.europa.eu/pvgis/apps4/pvest.php) we calculate the estimated production of electricity for an off grid $1 \mathrm{kWp}$ PV plant installed in Hrakleia (an arid island south of Naxos). It can reach $5.6 \mathrm{kWh} /$ day at June and July, which is sufficient enough to cover the fresh water needs of the 200 permanent residents, based on information from [11].

From fig. 8 it is obvious that the wind potential is really high in the studied areas as wind speed may reach 8-9 m/s. Several studies including $\mathrm{Ma}$ and $\mathrm{Lu}$ [40], Malek et. al [41], Arafat et. al [42] were conducted in regions were high wind potential was available. Wind turbines produce vast amounts of energy and therefore wind-driven desalination plants in Greek islands can achieve great capacity factors and therefore cover the needs of the islands.

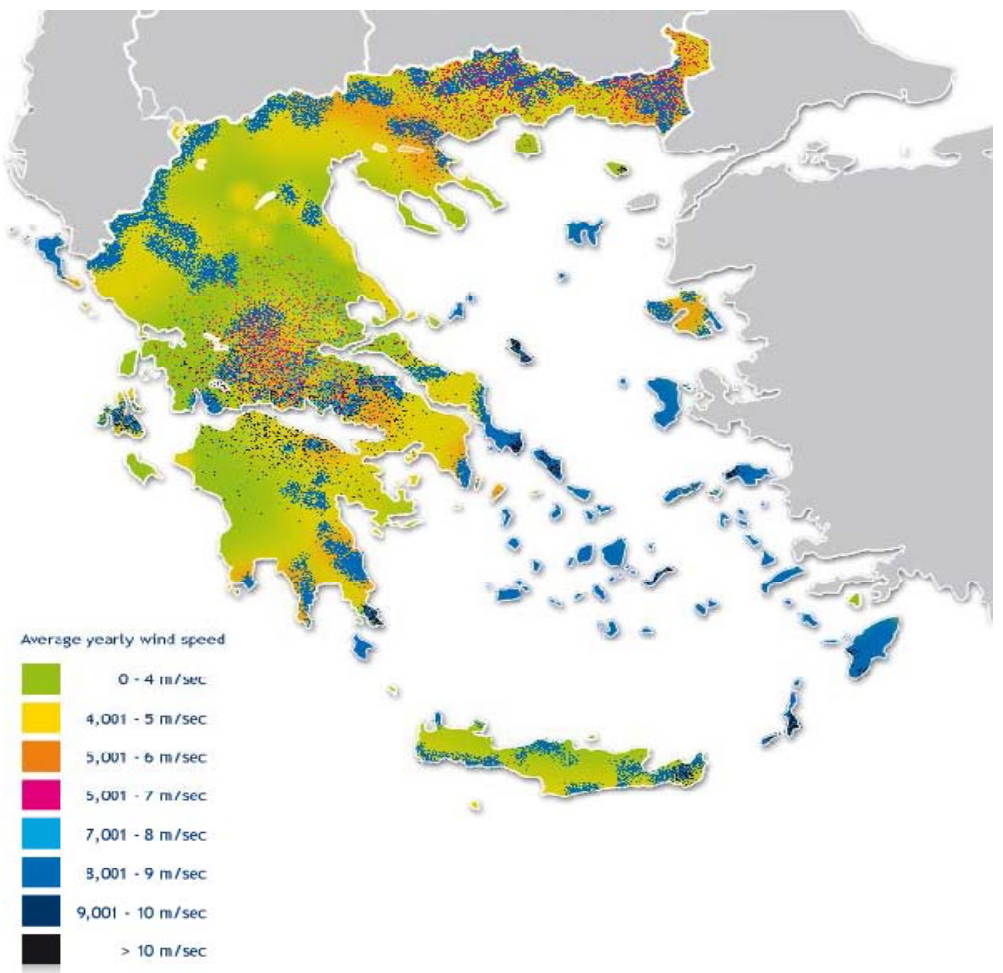

Fig.8 Annual wind speed map in Greece $\mathrm{m} / \mathrm{s}$ 


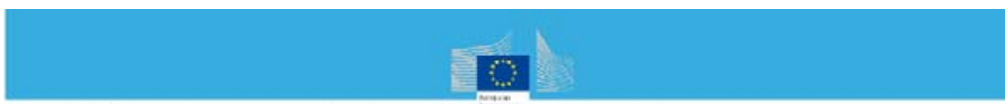

\section{Global irradiation and solar electricity potential} Horizontally mounted photovoltaic modules

GREECE / ENMADA

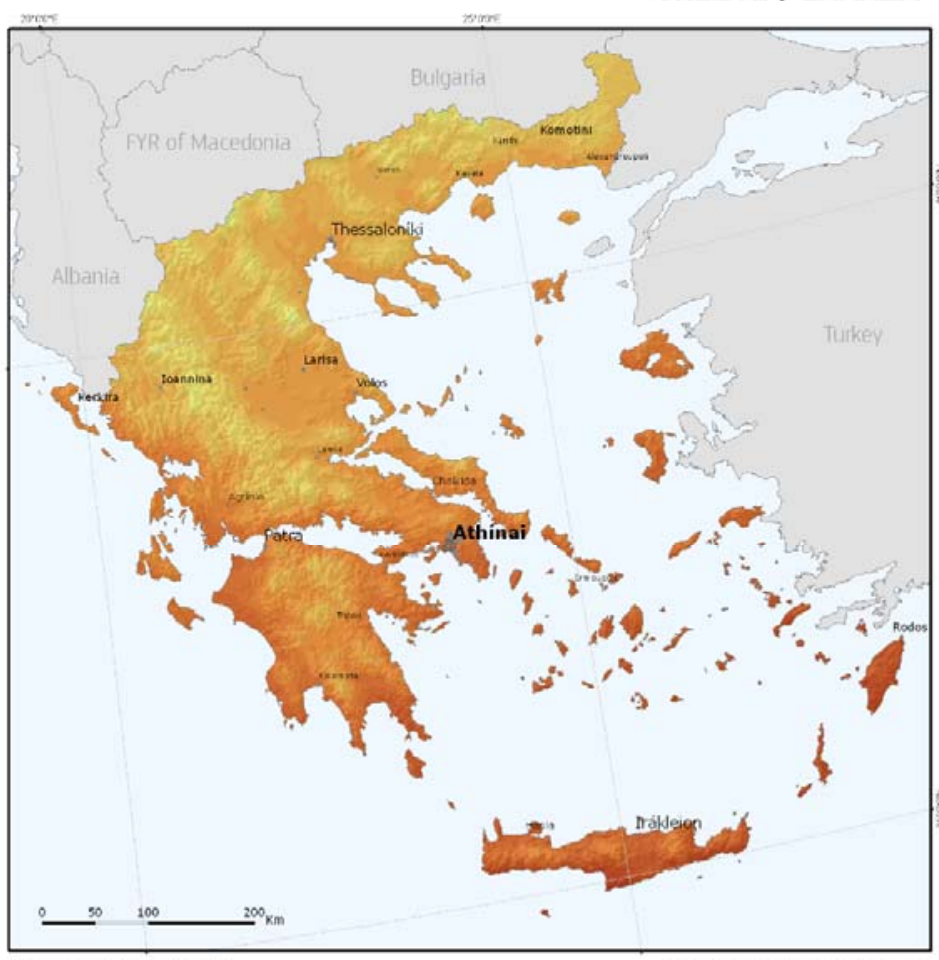

Yearly sum of global irradiation
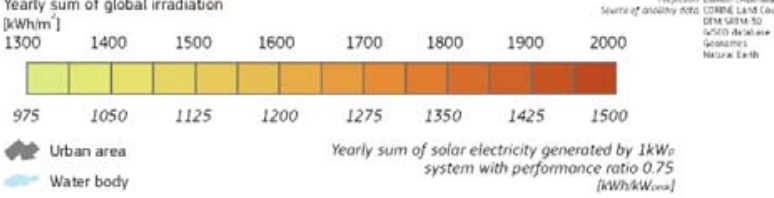

CM SAF

Fig.9: Annual solar irradiance in Greece $\left.\mathrm{kWh} / \mathrm{m}^{2}\right][39$

\section{Conclusions}

Almost all Aegean Islands used to cover their needs in water by the transported one that Greek government supplied to them. This solution to water scarcity didn't face the problem, but covered it temporarily. Last years since renewable energy sources penetrated local grids many municipalities from Aegean Islands undertook projects for PV or Wind driven desalination projects. In this way, they got advantage the abundance of wind and solar irradiance they have. Apart from that the environmental impact of the old, outdated desalination units operating with diesel is really high and adds to the 
already stained carbon footprint that tanker ships contribute. The Life Cycle Assessment method showed the great differences on the environmental impact between the two desalination units operating in Paros (with diesel) and in Milos operating with a wind turbine.

\section{References}

[1] Current status of water desalination in the Aegean Islands, Ioannis C. Karagiannis, Petros G. Soldatos, Desalination 203 (2007) 56-61

[2] Desalination units in Aegean islands, Ministry of energy and climate

[3] Stand-alone seawater RO (reverse osmosis) desalination powered by PV (photovoltaic) and PRO (pressure retarded osmosis), Wei He, Yang Wang, Mohammad Hasan Shaheed, Energy 86 (2015) $423 \mathrm{e} 435$

[4] Desalination using solar energy: Towards sustainability, Veera Gnaneswar Gude , Nagamany Nirmalakhandan, Shuguang Deng, Energy 36 (2011) 78e85

[5] Evaluation of the wind-hydro energy solution for remote islands, Kaldellis et al. Energy Conversion and Management 42 (2001) 1105-1120

[6] Design, simulation and economic analysis of a stand-alone reverse osmosis desalination unit powered by wind turbines and photovoltaics, Essam Sh. Mohamed, G. Papadakis, Desalination, Volume 164, Issue 1, 25 March 2004, Pages 87-97

[7] Water desalination cost literature: review and assessment, Ioannis C. Karagiannis, Petros G. Soldatos, Desalination, Volume 223, Issues 1-3, 1 March 2008, Pages 448-456

[8] Example of project development opportunities in Greece, Italy, Spain, Portugal. PRODES

[9] Green Islands in Europe and Prospects for Greek Islands. The Tilos Project, J.K. Kaldellis*, G. Salagiannis, N.C. Ilia, P. Stinis, K. Dimakis, International Conference 'Science in Technology' SCinTE 2015

[10] General Secretary of Aegean and Island Policy. http://www.ypai.gr/

[11] Technical and economic comparison between PV-RO system and RO-Solar Rankine system. Case study: Thirasia island, D. Manolakos, Essam Sh. Mohamed, I. Karagiannis, G. Papadakis, Desalination 221 (2008) 37-46

[12] Intakes and Outfalls for Seawater Reverse-Osmosis Desalination Facilities, Thomas M. Missimer Burton Jones Robert G. Maliva, Springer, 2015

[13] Technical feasibility comparison of off-grid PV-EDR and PV-RO desalination systems via their energy consumption, Leila Karimi , Leili Abkar, Masoud Aghajani, Abbas Ghassemi, Separation and Purification Technology 151 (2015) 82-94

[14] Asimakopoulos, Desalination Using fossil fuels on arid islands, 2010

[15] Sustainability in the construction industry: A review of recent developments based on LCA, Oscar Ortiza, Francesc Castells, Guido Sonnemann, Volume 23, Issue 1, January 2009, Pages 28-39

[16] I. Papadopoulos, Comparative Analysis of Electricity Generating Technologies with Regards to Environmental Burdens, Ph.D Thesis, University of Bath, UK, 2010

[17] Analysis of technology improvement opportunities for a 1.5 MW wind turbine using a hybrid stochastic approach in life cycle assessment, Matthew Ozoemena, Reaz Hasan, Wai Ming Cheung, Renewable Energy 93 (2016) 369e382

[18] United State Environmental Protection Agency. Office of Research and Development, Life Cycle Assessment: Inventory Guidelines and Principles, EPA/600/R-92/245, US; 1993

[19] S. Kumar, G.N. Tiwari, Life cycle cost analysis of single slope hybrid (PV/T) active solar still, Appl. Energy 86 (2009) 1995-2004.

[20] A.M. Helal, S.A. Al-Malek, E.S. Al-Katheeri, Economic feasibility of alternative designs of a PV-RO desalination unit for remote areas in the United Arab Emirates, Desalination 221 (1-3) (2008) 1 16.

[21] International Standardization Organization (ISO). Environmental management - life cycle assessment principles and framework; 2006. ISO 14040 
[22] Environmental impact and impact assessment of seawater desalination, Sabine Lattemann, Thomas Höpner, Desalination 220 (2008) 1-15

[23] Environmental life cycle analysis of a water pumping and desalination process powered by intermittent renewable energy sources, Habib Cherif, GérardChampenois, JamelBelhadj, RenewableandSustainableEnergyReviews59(2016)1504-1513

[24] Progress on drinking water and sanitation, 2012 update, unicef and world health organization

[25] Sustainable Desalination: Environmental Approaches, F. Lokiec, The International Desalination Association World Congress on Desalination and Water Reuse 2013 / Tianjin, China

[26] How green solar desalination really is? Environmental assessment using life-cycle analysis (LCA) approach, Kenan Jijakli, Hassan Arafat *, Scott Kennedy, Prasad Mande, Vijo Varkey Theeyattuparampil, Desalination 287 (2012) 123-131

[27] Water supply modeling towards sustainable environmental management in small islands: the case of Paros, Greece, D. Voivontasa, G. Arampatzis, E. Manoli, C. Karavitis, D. Assimacopoulos, Desalination 156 (2003) 127-135

[28] Desalination in Greek Islands by Using Res, A. Kartalidis, M. Georgopoulou, G. Arampatzis, D.Assimacopoulos, CEST2011 - Rhodes, Greece

[29] Investigating the energy autonomy of very small non-interconnected islands A case study: Agathonisi, Greece, J.K. Kaldellis , Ant. Gkikaki, El. Kaldelli, M. Kapsali, Energy for Sustainable Development 16 (2012) 476-485

[30] Renewable energy desalination plants for the Greek islands technical and economic considerations, J.K. Kaldellis, K.A. Kavadias , E. Kondili, Desalination 170 (2004) 187.203

[31] Optimised desalination of seawater by a PV powered reverse osmosis plant for a decentralised coastal water supply, Tomas Espino, Baltasar Peeate, Gonzalo Piernaviej, Dirk Herold, Apostel Neskakis, Desalination 156 (2003) 349-350

[32] Multi-criteria decision making on the energy supply configuration of autonomous desalination units, Dimitris Georgiou, Essam Sh. Mohammed, Stelios Rozakis, Renewable Energy 75 (2015) 459e467

[33] Energy and CO2 life-cycle analyses of wind turbines-review and applications, Manfred Lenzena, Jesper Munksgaard, Volume 26, Issue 3, July 2002, Pages 339-362

[34] Network of Distribution and Management of Electrical Power $(\Delta \mathrm{E} \Delta \Delta \mathrm{HE})$ http://www.deddie.gr/el/stoixeia-ekkathariseon-kai-minaion-deltion-mdn/2015

[35] Regulatory Authority for energy, Greece http://www.rae.gr/site/categories_new/electricity /market/mdn.csp

[36] IEA, Energy Statistics Manual, 2005

[37] Technical review and evaluation of the economics of water desalination: Current and future challenges for better water supply sustainability, Noreddine Ghaffour, Thomas M. Missimer, Gary L. Amy, Desalination 309 (2013) 197-207

[38] Desalination using solar energy: Towards sustainability, Veera Gnaneswar Gude Nagamany Nirmalakhandan, Shuguang Deng, Energy 36 (2011) 78 e85

[39] http://re.jrc.ec.europa.eu/pvgis/imaps/index.htm

[40] Wind energy technologies integrated with desalination systems: Review and state-of-the-art, Qingfen Ma, Hui Lu, Desalination 277 (2011) 274-280

[41] Decentralized desalination of brackish water using an electrodialysis system directly powered by wind energy, P. Malek, J.M. Ortiz, H.M.A. Schulte-Herbrüggen, Desalination 377 (2016) 54-64

[42] Wind-powered desalination for strategic water storage: Techno-economic assessment of concept, Savvina Loutatidou, Nikos Liosis, Robert Pohl, Taha B.M.J. Ouarda, Hassan A. Arafat, Desalination 408 (2017) 36-51 
